\title{
Tanggung Jawab Notaris dan PPAT Terkait Dengan Akta Jual Beli Tanah
}

\author{
Anak Agung Bagus Juniarta ${ }^{1}$, Gde Made Swardhana ${ }^{2}$
}

${ }^{1}$ Kantor Notaris Indi James Sihombing, S.H.,M.Kn , E-mail:agungbagus533@gmail.com 2Fakultas Hukum Universitas Udayana, E-mail: gmswar@yahoo.com

\begin{tabular}{l}
\hline Info Artikel \\
\hline Masuk: 15 Maret 2021 \\
Diterima:23 Juni 2021 \\
Terbit: 1 Juli 2021 \\
Keywords: \\
Notary Public, PPAT (Land \\
Titles Registrar) and \\
Responsible \\
\\
Kata kunci: \\
Notaris, PPAT (Pejabat \\
Pembuat Akta Tanah) dan \\
Tanggung Jawab \\
Corresponding Author: \\
Anak Agung Bagus Juniarta \\
E-mail: \\
agungbagus533@gmail.com \\
DOI: \\
10.24843/AC.2021.v06.i02.p10
\end{tabular}

\begin{abstract}
Thus this paper's purpose is to find out and review the duties, authorities of notaries and PPAT and to know and study about the responsibilities of notaries and PPAT in relation to the land sale and purchase deed they have made. The research method uses normative juridical. The results of this research state that notaries and PPATs are public officials who have an important function in making authentic deeds related to legal issues regarding land rights and ownership rights to apartment units and the responsibility of notaries and PPAT is responsible for the sale and purchase deeds made which causes deliberate loss and liability for unintentional losses, both civil and administrative.
\end{abstract}

\section{Pendahuluan}

\begin{abstract}
Abstrak
Adapun tujuan dari tulisan ini yakni untuk mengetahui dan mengkaji tentang tugas, wewenang notaris dan PPAT dan untuk mengetahui dan mengkaji tentang tanggung jawab notaris dan PPAT terkait dengan akta jual beli tanah yang dibuatnya. Penelitian ini menggunakan metode penelitian yuridis normatif. Hasil riset ini menyatakan bahwa notaris dan PPAT ialah pejabat umum yang memiliki fungsi penting dalam membuat akta otentik terkaittentang persoalan hukum terhadap Hak atas tanah dan Hak Milik atas satuan rumah susun dan tanggung jawab notaris serta PPAT adalah bertanggung jawab atas akta jual beli tanah yang dibuat yang menyebabkan terjadinya kerugian yang disengaja dan tanggung jawab terjadinya kerugian yang tidakdisengaja baik secara perdata dan administratif.
\end{abstract}

Indonesia merupakan negara hukum sehingga menjadikan hukum sebagai kekuasaan tertinggi di Indonesia. Hukum berfungsi sebagai pelindung dan menjamin ketentraman masyarakatnya. Sesuai dengan UUD NRI Tahun 1945 dalam pasal 1 ayat (3) mengatur "negara Indonesia ialah negara hukum". Pada Bab X pasal 27 ayat (1) mengatur "semua warga negara bersamaan dengan kedudukannya di dalam hukum dan pemerintah wajib menjunjung tinggi hukum".Pasal 28 ayat (5) mengatur "penegakan dan melindungi Hak Asasi Manusia (HAM) atas dasar prinsip negara 
yang demokratis, oleh karena itu HAM dijamin dan diatur dalam aturan perundangan. Aktivitas di Indonesia sepenuhnya diatur oleh hukum". Aktivitas ini termasuk kedalam jual beli tanah ini. Kegiatan ini harus bisa dilaksanakan secara aman.

Thomas Malthus sebagai ahli demografi dan ekonomi politik di linggris menyatakan Populasi manusia ini tumbuh dan berkembang berdasarkan deret ukur. Pertumbuhan manusia ini menyebabkan lahan tanah semakin sedikit. Aktivitas jual beli tanah semakin meningkat karena beberapa faktor yaitu: Tanah merupakan investasi masa depan ${ }^{1}$. Hal ini dibuktikan melalui harga tanah yang semakin lama semakin naik. Tanah merupakan lahan yang digunakan manusia sebagai tempat tinggal. ${ }^{2}$ Tingginya aktivitas jual beli tanah ini memicu beberapa pihak yang tidak bertanggung jawab yaitu melakukan penipuan dan perebutan hak atas tanah tersebut. Penipuan yang terjadi diakibatkan jual beli tanah tanpa memahami proses peralihan hak atas tanah melalui jual beli secara hukum.

Guna menjamin keamanan dan perlindungan hukum terhadap hak pribadi terkait jual beli tanah, transaksi tersebut harus sesuai dengan ketentuan hukum yang berlaku terkait dengan proses peralihan hak atas tanah melalui jual beli termasuk yang diatur dalam hukum perdata dan juga harus sesuai dengan hukum administrasi dalam hal ini hukum agraria. Hukum perdata merupakan hukum materiil yakni hukum yang mengatur mengenai perintah dan larangan. Dalam hal ini yaitu norma yang menjadi pedoman dalam proses peralihan hak atas tanah. Dalam Pasal 1866 KUHPerdata mengatur "alat-alat bukti terdiri dari:

1. Bukti dengan Tulisan

2. Bukti dengan beberapa Saksi-Saksi

3. Bukti dengan berbagai Persangkaan-Persangkaan

4. Bukti Pengakuan

5. Bukti Sumpah". 3

Hak atas tanah peralihannya dilakukan dengan akta. Akta merupakan tulisan yang sengaja dibuat oleh pihak tertentu yang dapat dijadikan sebagai alat bukti dan termasuk sebagai kekuatan pembuktian tertulis apabila terjadi peristiwa yang tidak diinginkan, seperti sengketa. Akta tersebut juga ditandatangani sebagai bukti sah ${ }^{4}$. Adapun fungsi akta terdiri dari 2 (dua) yakni fungsi formil dan materiil atau fungsi alat bukti. Fungsi formil adalah suatu fungsi untuk melengkapi atau menyempurnakan suatu pembuktian, sedangkan fungsi alat bukti merupakan fungsi yang digunakan sebagai bukti pada kemudian hari jika terdapat permasalahan sehingga akta bisa dipakai sebagai alat bukti. Dalam hal ini, akta terdiri atas 2 (dua), yaitu akta autentik dan akta dibawah tangan. Akta autentik merupakan akta yang

\footnotetext{
${ }^{1}$ Rachmad Setiawan.(2017). Tinjauan Elementer Perbuatan Melanggar Hukum. Bandung: Alumni, h.70.

2Kartono.(2018). Persetujuan Jual Beli Menurut Kitab Undang-undang Hukum Perdata, Cetakan 2. Jakarta: Pradnyana Paramita, h. 30.

${ }^{3}$ Tjukup, I. K., Layang, I. W. B. S., Martana, N. A., Markeling, I. K., Dananjaya, N. S., Arsha, I. P. R., ... \& Tribuana, P. A. R. (2016). Akta Notaris (Akta Otentik) Sebagai Alat Bukti Dalam Peristiwa Hukum Perdata. Jurnal Ilmiah Prodi Magister Kenotariatan, 2015, 180, doi https:// doi.org/10.24843/ AC.2016.v01.i02.p05 , h. 184

${ }^{4}$ Ibid.
} 
pembuatannya di depan notaris dan PPAT, sedangkan akta dibawah tangan yakni akta yang dibuat oleh pihak-pihak tidak dihadapan Notaris dan PPAT .

Akta otentik apabila digunakan maka transaksi secara hukum akan aman, terlindungi dan terjamin dikarenakan kekuatan pembuktian yang sempurna dari akta otentik, yakni apa yang dituangkan dalam akta adalah benar sepanjang dapat dibuktikan sebaliknya. Dalam hal ini, tidak perlu alat bukti lainnya untuk menambahkan keyakinan Hakim. ${ }^{5}$ Dalam kaitannya dengan PPAT, maka PPAT diberikan wewenang membuat akta peralihan hak atas tanah dan juga PPAT diberikan kewenangan untuk menjalankan sebagian kewenangan pemerintah perihal pendaftaran tanah. Dalam menjalankan kewenangannya tersebut, maka PPAT berpedoman pada UU No. 5/1960 tentang Peraturan Dasar Pokok-Pokok Agraria dan PP No. 24/1997 tentang Pendaftaran Tanah). Pada Pasal 19 ayat (2) UU No.5/1960 mengatur "Pendaftaran tersebut dalam ayat (1) pasal ini meliputi pendaftaran hak-hak atas tanah dan peralihan hakhak tersebut".

Akta PPAT ini dijadikan sebagai landasan kuat untuk mendaftarkan pengalihan hak dan membebani hak bagi para pihak. Berdasarkan Pasal 37 ayat (1) PP No.24/1997, tentang peralihan benda-benda dan tanah diatasnya dilakukan dengan akta yang dibuat oleh PPAT. Untuk pengalihan tanah dari pemilik pada yang menerima diikuti penyerahan yuridis, yaitu pemenuhan formalitas UU, yakni memenuhi syarat dan melewati mekanisme sebagaimana Pasal 45 PP No.24/1997 mengatur:

a. "Sertipikat atau surat keterangan tentang keadaan hak atas tanah harus sesuai dengan daftar-daftar yang ada pada kantor Pertanahan

b. Perbuatan hukum sebagaimana dimaksud dalam pasal 37 ayat (1) harus dibuktikan dengan akta PPAT atau kutipan risalah lelang sebagaimana dimaksud dalam Pasal 41, kecuali dalam keadaan tertentu sebagimana dimaksud dalam Pasal 37 ayat (2);

c. Dokumen yang diperlukan untuk pendaftaran peralihan atau pembebanan hak yang bersangkutan harus lengkap;

d. Dipenuhinya syarat lain yang ditentukan dalam peraturan perundangundangan yang bersangkutan;

e. Tanah yang bersangkutan tidak merupakan obyek sengketa di Pengadilan;

f. Perbuatan hukum yang dibuktikan dengan akta PPAT tidak batal atau dibatalkan oleh putusan Pengadilan yang telah memperoleh kekuatan hukum tetap; atau

g. Perbuatan hukum sebagaimana dimaksud dalam Pasal 37 ayat (1) tidak dibatalkan oleh para pihak sebelim didaftar oleh Kantor Pertanahan".

Dalam hal ini, Notaris dan PPAT harus mempunyai pemahaman yang cukup pada bidang pertanahan agar dapat menjalankan kewenangannya untuk membuat akta-akta pertanahan agar dikemudian hari tidak menimbulkan suatu persoalan dikarenakan akta yang dibuatnya akan menjadi alat bukti yang sah. Akta PPAT memiliki landasan yang kuat dan mutlak karena merupakan akta autentik. Notaris dan PPAT ini harus memiliki keahlian dibidangnya yaitu pertanahan. Keahlian ini mencakup Peraturan

${ }^{5}$ Ibid, h. 182. 
Dasar Pokok-Pokok Agraria, Kecakapan dan kemampuan ini perlu dimiliki notaris dan PPAT sebagai dasar pengetahuan dalam membuat akta tanah. Apabila Notaris dan PPAT tidak paham mengenai hukum agraria, maka pembuatan akta tanah dilakukan secara tidak bertanggung jawab, Dari uraian latar belakang adapun rumusan masalah riset ini yaitu bagaimana tugas, wewenang notaris dan PPAT dan bagaimana tanggung jawab notaris dan PPAT terkait dengan akta jual beli tanah yang dibuatnya. Tujuan penelitian ini untuk mengidentifikasi fungsi-fungsi dan Tanggung jawab notaris serta PPAT sebagai pejabat negara pembuat akta otentik.

Mengenai mekanisme serta formalitas dalam membuat akta autentik ini merupakan suatu ketetapan hukum bersifat memaksa, berarti mekanisme dalam membuat akta autentik ini mesti dijalankan dengan tepat dan tidak boleh disimpangi sekecil apapun. Dari mekanisme yang menyimpang dalam membuat akta autentik ini bisa berdampak hukum pada kegiatan membuktikan akta tersebut. Posisi akta autentik atau pejabat umum di Indonesia dimuat dalam Pasal 1868 KUHP yang menegaskan bahwa harus ada UU yang mengatur terkait bentuk akta autentik dan pejabat umum secara jelas. Saat ini masih ada PP 37/1998 mengenai aturan jabatan PPAT yang memuat bahwa "PPAT ialah pejabat umum yang mempuyai kewenangan membuat akta autentik..." Dalam arti luas yakni mencetak akta sesuai ketentuan bentuk oleh UU termasuk kegiatan menyiapkan, menyusun, serta membuat akta atas dasar bentuk yang ada dan sesuai dengan peraturan. Berdasarkan uraian latar belakang tersebut, adapun permasalahan yang dipaparkan yaitu bagaimana tanggung jawab notaris dan PPAT terkait dengan akta jual beli tanah.

Tujuan dalam penulisan ini yakni mengetahui dan mengkaji tentang pertanggung jawaban notaris dan PPAT terkait dengan akta jual beli tanah. Penelitian yang dilakukan oleh Penulis berfokus pada "kekosongan norma yakni dalam peraturan perundang-undangan yang terkait PPAT belum diatur secara khusus mengenai sanksi perdata dan pidana bagi PPAT apabila PPAT melakukan pelanggaran atau kesalahan dalam membuat akta jual beli". Penelitian terdahulu dilakukan oleh Yoshandi Raka Pradipta pada tahun 2014 yang berjudul "Tanggung Jawab Notaris Dalam Kelalaian Membuat Akta Jual Beli Tanpa Melihat Dokumen Asli (Studi kasus Putusan Peninjauan Kembali Perkara Perdata No.49 PK/PDT/2009 tanggal 16 september 2009)"6. Penelitian tersebut berfokus pada "penyebab akta otentik yang dibuat dihadapan Notaris mengakibatkan batal demi hukum, dan juga mengetahui dan menganalisis Tanggung Jawab Notaris dalam kelalaian membuat Akta Jual Beli tanpa melihat dokumen asli berdasarkan studi kasus Putusan Peninjauan Kembali Perkara Perdata No 49 PK/PDT/2009 tertanggal enam belas september dua ribu sembilan". Sedangkan penelitian yang dilakukan penulis berfokus pada "tanggung jawab notaris dan PPAT terkait dengan akta jual beli tanah". Penelitian selanjutnya dilakukan oleh Hatta Isnaini Wahyu Utomo dan Hendry Dwicahyo Wanda pada tahun 2017 berjudul “Prinsip Kehati-Hatian Pejabat Pembuat Akta Tanah dalam Peralihan Tanah yang

\footnotetext{
${ }^{6}$ Pradhipta, Y. R., \& Imanullah, M. N. (2019). Tanggung Jawab Notaris Dalam Kelalaian Membuat Akta Jual Beli Tanpa Melihat Dokumen Asli (Studi Kasus Putusan Peninjauan Kembali Perkara Perdata No. 49. Pk/Pdt/2009 Tanggal 16 September 2009). Jurnal Repertorium, 6(1), 16, ISSN 2355-2646 https://jurnal.uns.ac.id/repertorium/article/view/27830/19194, h.1.
} 
Belum Bersertipikat"7. Penelitian tersebut berfokus pada "Peralihan tanah yang belum bersertipikat tersebut rawan menimbulkan sengketa apabila PPAT tidak menerapkan prinsip kehati-hatian". Penelitian yang dilakukan oleh Penulis berfokus "pada tanggung jawab notaris dan PPAT terkaut dengan akta jual beli tanah". Berdasarkan pendahuluan ini, maka Penulis tertarik mengangkat judul "Tanggung Jawab Notaris Dan PPAT Terkait dengan Akta Jual Beli Tanah".

\section{Metode Penelitian}

Riset ini memakai metode yuridis normatif karena berpedoman pada peraturan perundang-undangan. Pendekatan yang dipakai: statute approach, conceptual approach, serta analytical approach. Adapun sumber bahan hukum yang dipakai yakni bahan hukum primer yang berpedoman pada peraturan perundang-undangan dan bahan hukum sekunder berpedoman pada buku maupun penelitian-penelitian jurnal terdahulu. Untuk teknik pengumpulan bahan hukum menggunakan teknik analisis kualitatif dan teknik studi dokumen.

\section{Pembahasan Dan Hasil}

\subsection{Fungsi Notaris dan PPAT Sebagai Pejabat Negara Pembuat Akta Otentik}

\subsubsection{Notaris}

Pasal 1 angka 1 UU No.2/2014 tentang Perubahan Atas UU No. 30/2004 tentang Jabatan Notaris bahwa "Notaris pejabat umum yang berwenang untuk membuat akta autentik dan memiliki kewenangan lainnya sebagaimana dimaksud dalam UndangUndang ini atau berdasarkan undang-undang lainnya". Adapun kewenangan Notaris sebagaimana dalam Pasal 15 ayat (1) dan ayat (2) UU No.2/2014 yakni:

(1) "Notaris berwenang membuat Akta autentik mengenai semua perbuatan, perjanjian, dan penetapan yang diharuskan oleh peraturan perundangundangan dan/atau yang dikehendaki oleh yang berkepentingan untuk dinyatakan dalam Akta autentik, menjamin kepastian tanggal pembuatan Akta, menyimpan Akta, memberikan grosse, salinan dan kutipan Akta, semuanya itu sepanjang pembuatan Akta itu tidak juga ditugaskan atau dikecualikan kepada pejabat lain atau orang lain yang ditetapkan oleh undang- undang.

2. Selain kewenangan sebagaimana dimaksud pada ayat (1), Notaris berwenang pula:

a. mengesahkan tanda tangan dan menetapkan kepastian tanggal surat di bawah tangan dengan mendaftar dalam buku khusus;

b. membukukan surat di bawah tangan dengan mendaftar dalam buku khusus;

c. membuat kopi dari asli surat di bawah tangan berupa salinan yang memuat uraian sebagaimana ditulis dan digambarkan dalam surat yang bersangkutan;

d. melakukan pengesahan kecocokan fotokopi dengan surat aslinya;

7 Isnaini,H., \& Wanda, H. D. (2017). Prinsip Kehati-Hatian Pejabat Pembuat Akta Tanah dalam Peralihan Tanah yang Belum Bersertifikat. Jurnal Hukum Ius Quia Iustum, 24(3), 467-487, doi https://doi.org/10.20885/iustum.vol24.iss3.art7 ,h.467. 
e. memberikan penyuluhan hukum sehubungan dengan pembuatan Akta;

f. membuat Akta yang berkaitan dengan pertanahan; atau

g. membuat Akta risalah lelang."

\subsubsection{PPAT (Pejabat Pembuat Akta Tanah)}

Pasal 1 angka 1 PP 37/1998. Mengatur "Pejabat Pembuat Akta Tanah, selanjutnya disebut PPAT adalah pejabat umum yang diberi kewenangan untuk membuat aktaakta otentik mengenai perbuatan hukum tertentu mengenai hak atas tanah atau Hak Milik Atas Satuan Rumah Susun". Kedudukan PPAT ini dikuatkan melalui beberapa peraturan perundangan yaitu:

1. Pasal 1 angka 4 UU No.4/1996 tentang Hak Tanggungan Atas Tanah Beserta kebendaan Yang Berkaitan Dengan Tanah mengatur "Pejabat Pembuat Akta Tanah, yang selanjutnya disebut PPAT, adalah pejabat umum yang diberikan kewenangan pembuatan akta pembebanan hak atas tanah, pergantian hak atas tanah, dan pemberian kuasa yang membebani hak tanggungan yang diatur berdasarkan ketetapan perundangan".

2. Atas dasar PP No. 24/1997 tentang Pendaftaran Tanah, Pasal 1 angka 24 mengatur "Pejabat Pembuat Akta Tanah, selanjutnya disebut PPAT adalah Pejabat umum yang diberi kewenangan untuk membuat akta-akta tanah tertentu".

3. Berdasarkan PP No.24/2016 tentang Perubahan Atas PP No. 37/1998 tentang Peraturan Jabatan Pejabat Pembuat Akta Tanah, Pasal 1 angka 1 mengatur "Pejabat Pembuat Akta Tanah, selanjutnya disebut PPAT adalah pejabat umum yang diberi kewenangan untuk membuat akta-akta otentik mengenai perbuatan hukum tertentu mengenai ha katas tanah atau Hak Milik Atas Satuan Rumah Susun".

PPAT mempunyai wewenang mengeluarkan akta perihal pertanahan agar akta yang dikeluarkannya tidak ada persoalan di waktu mendatang karena aktanya bersifat autentik sehingga bisa dipergunakan menjadi alat bukti yang valid dan memiliki dasar hukum yang kuat. Untuk sekarang ini tidak jarang didalam prakteknya PPAT ini mengeluarkan akta jual beli yang menyimpang dari mekanisme yang berdasarkan ketetapan aturan perundangan, sehingga hal itu dapat mendatangkan kerugian bagi pihak yang berkepentingan. ${ }^{8}$

Dalam hal dibutuhkan PPAT didaerah terpencil, maka camat dapat menjabat sebagai PPAT Sementara karena kondisi dan situasi yang ditentukan. Seseorang PPAT Sementara memerlukan syarat agar dapat menjabat. Beberapa syarat yang harus dipenuhi adalah seseorang PPAT Sementara merupakan lulusan sarjana hukum dan strata dua dalam bidang kenotariatan. Selain itu, untuk menjabat sebagai PPAT Sementara dapat mengikuti kegiatan pelatihan dan pendidikan khusus mengenai PPAT yang dilaksanakan oleh kementrian agraria. Tugas pokok yang harus dilakukan

8Ridodi, M. A. (2017). Batasan Kewenangan Notaris dan PPAT dalam Membuat Akta yang Berkaitan dengan Tanah. Lambung Mangkurat Law Journal, 2(1), 144735, e-ISSN: 2502-3128, http://lamlaj.ulm.ac.id/web/, h.99 
sebagai PPAT adalah melayani kebutuhan masyarakat, melayani akta pengalihan hak milik tanah dan melayani akta pemberian kuasa pembebanan hak tanggungan yang sudah ditetapkan oleh aturan perundangan yang masih berlaku. ${ }^{9}$

Dalam pembuatan akta otentik, adapun beberapa unsur harus dipenuhi berdasarkan Pasal 1868 KUHPerdata yakni:

1. “Akta tanah ini pembuatannya wajib dilakukan oleh dan di depan seorang pejabat umum yang berwenang dan bertugas;

2. Akta tanah ini pembuatannya wajib sesuai bentuk yang ditetapkan berdasarkan aturan perundangan yang berlaku di Indonesia;

3. Pejabat umum yang memuat akta harus telah memiliki kewenangan dalam pembuatannya, baik kewenangan atas dasar daerah (wilayah) kerjanya atau waktu pada pembuatan akta".

\subsection{Kewajiban Notaris dan PPAT}

Notaris sebagai pejabat Negara memiliki kewajiban dalam menjalankan tugasnya. Kewajiban itu diatur dalam Pasal 16 UU No.30/2004 j.o UU No.2/2014 tentang Jabatan Notaris yakni:

1. “Bersikap jujur, amanah, mandiri, saksama, tak memihak dan menjaga kepentingan pihak berkaitan yang sedang melakukan tindakan hukum

2. Membuat Akta dan disimpan sebagai protokol notaris

3. Melekatkan warkah-warkah serta sidik jari penghadap pada minuta akta

4. Mengeluarkan grosse akta, kutipan akta dan salinan akta

5. Melayani sesuai dengan ketentuan dalam UU.

6. Merahasiakan akta dan semua keterangan yang didapatkan untuk membuat Akta berdasarkan sumpah serta janji jabatan.

7. Menjilid akta setiap bulan menjadi buku yang berisi kurang dari 50 akta. Apabila tidak memuat satu buku maka diperbolehkan membuat lebih dari satu buku. Pencatatan tersebut meliputi jumlah akta, tanggal dan tahun

8. Membuat daftar akta protes

9. Membuat daftar akta wasiat

10. Memiliki cap dan stempel dengan cantuman lambang negara Republik Indonesia dan ditulisi nama, jabatan dan kedudukan

11. Membacakan akta di depan penghadap yang diikuti minimal 2 orang saksi, 4 orang saksi khusus agar membuat wasiat di bawah tangan dan ditandatangani waktu pembuatan akta.

12. Menerima calon notaris" 10

Mengenai tugas dan wewenang PPAT diatur dalam Pasal 2 ayat (1) PP No.24/2016 jo. No. 37/1998 yang mengatur "PPAT memiliki wewenang dan tugas pokok untuk melakukan sebagian aktivitas dari proses pendaftaran tanah serta membuat akta

9Oloan, N. (2016). Praktek Pembuatan Akta Tanah oleh Camat dalam Kedudukan dan FungsinyaSelaku PPAT Sementara di Kota Padangsidimpuan. JUPIIS: IURNAL PENDIDIKAN ILMU-ILMU SOSIAL, 8(2), doi https:// doi.org/10.24114/jupiis.v8i2.5158.g4578 , h.124.

${ }^{10}$ Darusman, Y. M. (2016). Kedudukan notaris sebagai pejabat pembuat akta otentik dan sebagai pejabat pembuat akta tanah. ADIL: Jurnal Hukum,7(1), 36-56, doi https:// doi.org/10.33476/ajl.v7i1.331 , h.48. 
sebagai bukti yang sah dalam pelaksanaan tindakan hukum tertentu tentang Hak Milik Atas dan hak atas tanah, yang dipakai sebagai landasan untuk pendaftaran dalam merubah data akibat perbuatan hukum itu sendiri".

Kewajiban yang telah diatur dalam perundang-undangan harus sudah dijalankan penuh dan tidak boleh dilanggar. Tanggung jawab sebagai notaris diwujudkan melalui kewajiban yang telah dilakukan. Kewajiban notaris ini sangat penting demi menjaga keamanan dan melindungi masyarakat dalam menjalankan kegiatan jual beli termasuk jual beli tanah. Selanjutnya, PPAT sebagai pejabat negara juga memiliki kewajiban. Kewajiban PPAT telah dimuat di Pasal 2 Ayat 2 PP No.24/2016 jo. PP No. 37/1998 yang mengatur:
a. "Jual beli.
b. Tukar menukar
c. Hibah
d. Pemasukan ke dalam perusahaan
e. Pembagian hak guna bangunan atau hak pakai atas Tanah Hak Milik
f. Pembagian hak Bersama
g. Pemberian hak tanggungan
h. Pemberian kuasa memberikan hak tanggungan"11

\subsection{Tanggung Jawab Notaris dan PPAT}

\subsubsection{Tanggung Jawab Keperdataan}

Menurut Roscoe Pound bahwa pertanggung jawaban hukum atas delik ada tiga yaitu:

1. “Tanggung jawab atas terjadinya kerugian yang disengaja

2. Tanggung jawab atas terjadinya kealpaan serta kerugian yang tidak disengaja

3. Tanggung jawab atas perkara tertentu dan terjadi kerugian karena kelalaian yang telah dilakukan secara tidak disengaja12"

Dari pengetahuan yang telah dikemukakan oleh Roscoe Pound bahwa PPAT harus siap bertanggung jawab atas kerugian yang terjadi. Kerugian ini baik dilakukan secara tidak disengaja maupun disengaja. Bentuk kerugian ini dapat dicontohkan dengan pembuatan atas akta tanah yang dibuat secara tidak sempurna. Kegiatan ini akan merugikan pihak penghadap apabila dikemudian hari terjadi suatu permasalahan.

Apabila akta PPAT tidak memenuhi persyaratan sebagai akta otentik, maka akta tersebut tidak bisa disebut sebagai akta otentik dan tidak memiliki kekuatan pembuktian yang sempurna. Akibatnya adalah para pihak dapat mengalami kerugian. Kerugian yang terjadi semacam ini harus segera ditindak lanjuti dan merupakan tanggung jawab penuh atas tugas PPAT. ${ }^{13}$

Apabila PPAT tidak bertanggung jawab atas kerugian tersebut, maka akan menyebabkan pihak terkait hilang atas hak-hak perlindungannya dari hukum perdata apabila terjadi suatu permasalahan dikemudian hari. Akibat kelalaian dan kesalahan

\footnotetext{
${ }^{11}$ Ibid.

12 Widodo, MuhkamArief.(2015).Pertangqungiawaban Perdata Notaris Akibat Penyalahounaan Kerahasiaan Minuta Akta Oleh Pekerjanya. (Magister thesis, Universitas Brawijaya), h.14.

${ }^{13}$ Ibid,h 15 .
} 
PPAT mengeluarkan akta menyebabkan tidak sah-nya akta tersebut sebagai alat bukti. Bentuk tanggung jawab PPAT berupa ganti rugi ialah:

1. Ganti rugi umum, ialah peraturan yang berlaku bagi seluruh jenis kasus yang disebabkan kerena suatu perbuatan melawan hukum seperti bunga dan biaya .untuk permasalahan ganti rugi secara umum ini ada didalam pasal 1234 sampai dengan 1252 KUHPerdata.

2. Ganti rugi khusus, ialah ganti rugi yang hanya bisa muncul dari perjanjian perjanjian tertentu saja.

3. Ganti rugi berupa uang. Ganti rugi ini berupa ganti rugi sejumlah uang terhadap kerugian pihak tersebut.

4. Ganti rugi dalam wujud lain, ialah ganti rugi jika pihak yang dirugikan tidak menerima ganti rugi berupa pembayaraan sejumlah uang, sehingga bisa meminta bentuk ganti rugi yang lain, maka atas peradilan hukum pihak terkait harus mengikuti permintaan pihak yang dirugikan. ${ }^{14}$

\subsubsection{Tanggung Jawab Administratif}

Tanggung jawab administratif harus dilakukan seorang PPAT apabila melakukan pelanggaran dan kesalahan. Pelanggaran dan kesalahan PPAT ini mencakup kelalaian perihal membuat akta pendaftaran dan peralihan Hak atas Tanah. Kelalaian ini dapat menimbulkan konsekuensi hukum sehingga PPAT harus bertanggung jawab. Bentuk tanggung jawab tersebut dikategorikan menurut Kranenburg dan Vegtig yaitu: ${ }^{15}$

1. Fautes Personalles merupakan bentuk tanggung jawab yang dibebankan kepada Pejabat karena telah melakukan kegiatan yang merugikan bagi pihak terkait. Tanggung jawab semacam ini merupakan tanggung jawab yang dilakukan secara pribadi.

2. Fautes de Services merupakan bentuk tanggung jawab oleh instansi dari pejabat yang bersangkutan. Kerugian yang diterima oleh pihak terkait merupakan tanggung jawab instansi pejabatnya bukan diri pribadi seorang pejabat. Tanggung jawab ini akan disesuaikan dengan tingkat berat dan ringannya kesalahan yang telah dilakukan. Perbuatan kesalahan baik ringan maupun berat tetap sama saja akan berimbas pada jabatannya serta tetap harus bertanggung jawab.

Sesuai dengan penjelasan tanggung jawab secara administratif diatas PPAT tetap sepenuhnya harus bertanggung jawab. Menerima beban tanggung jawab terhadap kesalahan dan kelalaian yang telah dilakukan. Kelalaian ini berupa kesalahan pembuatan akta tanah yang mengandung cacat hukum tersebut. wewenang tersebut apabila dilakukan kesalahan dan kelalaian secara sengaja dan tidak sengaja maka akan tetap mendapatkan sanksi. ketika pelanggaran atas wewenang terjadi maka wajib bagi PPAT bertanggung jawab secara administratif. Kewajiban bertanggung jawab secara administratif ini juga tersusun di Pasal 62 PP No.24/1997 yang berisi: Bagi PPAT yang menjalankan kewenanangannya tidak sesuai ketetapan yang telah diatur pada pasal 38, 39 dan 40 maka akan mendapat teguran tertulis hingga teguran memberhentikan masa jabatannya sebagai PPAT. Maka dari itu seorang PPAT juga memiliki kode etik

14Rachmad Setiawan.Loc.Cit.

15Soerjono, Soekanto. (2017).Pengantar Penelitian Hukum. Jakarta: Universitas Indonesia, h.160. 
yang tidak bisa dilanggar. Apabila kode etik sebagai PPAT dilanggar maka akan mendapatkan hukuman berupa :
1. Teguran
2. Peringatan
3. Schorsing
4. Onzetting
5. Pemberhentian secara tidak hormat

Hukuman diatas merupakan bentuk hukuman dari yang paling ringan hingga berat. hukuman tersebut akan diberlakukan apabila seorang PPAT melanggar kode etik ${ }^{16}$. Pertama, PPAT yang melanggar kode etik akan diberi teguran. teguran ini berupa pemberian arahan. Kedua, diberikan peringatan. Apabila telah diberi peringatan maka kesalahan yang telah dilakukan PPAT ini sedikit berpengaruh. Ketiga, schorsing. schosing disini adalah pemberhentian menjadi PPAT secara sementara. Kesalahan yang dilakukan cukup berat sehingga PPAT harus diberhentikan secara sementara. Keempat, onzetting adalah pemberhentian secara permanen dari keanggotaan PPAT karena telah melakukan pelanggaran yang sangat berat sehingga harus diberhentikan secara permanen dari keanggotaan PPAT. Kelima yaitu pemberhentian secara tidak hormat.

Apabila akta PPAT yang terbit tidak sesuai aturan akibat disengaja atau lalai maka PPAT wajib ada pertanggungjawaban baik secara moril atau hukum tertulis. Sebab dari persoalan ini dapat muncul dengan langsung yang diakibatkan oleh pelanggaran PPAT atau pun muncul dengan tidak langsung akibat perbuatan orang lain. Jika sebabnya karena PPAT lalai, sehingga akan berdampak akta itu hanya memiliki kekuatan pembuktian dibawah tangan ataupun bisa adanya pembatalan, sebab tak dapat memenuhi persyaratan secara subyektif yang dapat dipakai sebagai alasan untuk kerugian pihak tertentu sehingga bisa adaya tuntutan ganti rugi pada pihak PPAT. Selain faktor PPAT, kesalahan lain bisa diakibatkan oleh karena ketidak jujuran klien dalam menyampaikan atau memberikan persyaratan administratif yang dibutuhkan sehingga menyebabkan akta bisa dibatalkan secara hukum, karena persyaratan objektif tidak dipenuhi ${ }^{17}$. Oleh karena itu, apabila PPAT melakukan kesalahan perihal pembuatan akta jual beli atau dengan kata lain akta jual beli yang dibuat oleh PPAT tersebut terdapat cacat hukum, maka akta tersebut batal demi hukum, dan PPAT dapat dikenakan sanksi perdata berdasarkan KUHPerdata dan sanksi administrasi. 18

Bentuk pemberhentian secara tidak hormat ini dikarenakan seorang PPAT melanggar kode etik sehingga sudah tidak dapat lagi diberhentikan secara hormat. Maka, pemberhentian harus dilakukan secara tidak hormat. sanksi-sanksi atau hukuman

16Mochtar Mas'oed.(2017). Tanah dan Pembangunan.Jakarta: Pustaka Sinar Harapan, h. 95.

${ }_{17}$ Wibawa, K. C. S. (2019). Menakar Kewenangan dan Tanggung Jawab Pejabat Pembuat Akta Tanah (PPAT) dalam Perspektif Bestuurs Bevoegdheid. CREPIDO, 1(1), 40-51, doi https://doi.org/10.14710/crepido.1.1.40-51, h.49.

${ }^{18}$ Febriana, D. T., \& Sulaiman, A. (2019). Tanggung Jawab Pejabat Pembuat Akta Tanah (PPAT) Dalam Pembuatan Akta Jual Beli Tanah Berdasarkan Peraturan Pemerintah Republik Indonesia Nomor 24 Tahun 2016 Tentang PPAT.Jurnal Petita, 1(1), doi https://doi.org/10.33373/pta.v6i1.1868, h.123. 
yang ada diatas dijatuhkan kepada pejabat PPAT yang tidak menjalankan kode etik berdasarkan kuantitas dan kualitas kesalahan yang dibuat oleh PPAT. Apabila kesalahan yang dilakukan ringan maka akan mendapat hukuman ringan juga. kesalahan yang dilakukan berat maka akan mendapat sanksi dan teguran yang berat juga. 19

\section{Kesimpulan}

Notaris ialah seseorang yang diangkat pemerintah negara menjadi pejabat negara yang bertugas membuat akta tanah tentang seluruh perbuatan, perjanjian dan ketentuan yang diwajibkan oleh aturan perundangan dan atau atas kehendak para pihak agar dinyatakan dalam akta autentik, serta mengesahkan dan melegalisasi pengikatan oleh masyarakat. Notaris sebagai PPAT ialah "Pejabat Pembuat Akta Tanah, selanjutnya disebut PPAT adalah pejabat umum yang diberi kewenangan untuk membuat aktaakta otentik mengenai perbuatan hukum tertentu mengenai hak atas tanah atau Hak Milik Atas Satuan Rumah Susun" sesuai dengan Pasal 1 angka 1 PP No. 37/1998. Baik Notaris maupun PPAT mempunyai tanggung jawab yaitu pertama tanggung jawab perihal akta jual beli tanah yang dibuat yang menyebabkan terjadinya kerugian yang disengaja, kedua, Tanggung jawab atas perkara tertentu dan terjadi kerugian karena kelalaian yang telah dilakukan secara tidak disengaja, dan mengenai hal tersebut maka perlu diatur secara khusus mengenai sanksi bagi Notaris dan PPAT, yakni diatur lebih lanjut mengenai sanksi pidana dan sanksi perdata dalam perturan perundangundangan yang terkait dengan PPAT sehingga Notaris dan PPAT tidak lalai dalam tugas dan kewenangannya dalam menjalankan jabatannya.

\section{Daftar Pustaka}

\section{$\underline{\text { Buku }}$}

Kartono.(2018). Persetujuan Jual Beli Menurut Kitab Undang-undang Hukum Perdata, Cetakan 2. Jakarta: Pradnyana Paramita

Mas'oed Mochtar. (2017). Tanah dan Pembangunan.Jakarta: Pustaka Sinar Harapan

Setiawan Rachmad. (2017). Tinjauan Elementer Perbuatan Melanggar Hukum.Bandung: Alumni

Soekanto Soerjono.( 2017).Pengantar Penelitian Hukum. Jakarta: Universitas Indonesia

\section{Jurnal Ilmiah}

Darusman, Y. M. (2016). Kedudukan notaris sebagai pejabat pembuat akta otentik dan sebagai pejabat pembuat akta tanah. ADIL: Jurnal Hukum, 7(1), 36-56, doi https://doi.org/10.33476/ajl.v7i1.331

Febriana, D. T., \& Sulaiman, A. (2019). Tanggung Jawab Pejabat Pembuat Akta Tanah (PPAT) Dalam Pembuatan Akta Jual Beli Tanah Berdasarkan Peraturan

${ }^{19}$ Kristanto, Y., Budiartha, I. N. P., \& Arini, D. G. D. (2020). Tanggung Jawab dan Wewenang Notaris/PPAT terhadap Kekeliruan dan Pembatalan Akta Jual Beli Tanah. Jurnal Interpretasi Hukum, 1(2), 197-202, doi https://doi.org/10.22225/juinhum.1.2.2465.197-202 , h.200 
Pemerintah Republik Indonesia Nomor 24 Tahun 2016 Tentang PPAT. Jurnal Petita, 1(1), doi https://doi.org/10.33373/pta.v6i1.1868

Isnaini, H., \& Wanda, H. D. (2017). Prinsip Kehati-Hatian Pejabat Pembuat Akta Tanah dalam Peralihan Tanah yang Belum Bersertifikat. Iurnal Hukum Ius Quia Iustum, 24(3), 467-487. doi https://doi.org/10.20885/iustum.vol24.iss3.art7

Kristanto, Y., Budiartha, I. N. P., \& Arini, D. G. D. (2020). Tanggung Jawab dan Wewenang Notaris/PPAT terhadap Kekeliruan dan Pembatalan Akta Jual Beli Tanah. Iurnal Interpretasi Hukum, 1(2), 197-202, doi https://doi.org/10.22225/juinhum.1.2.2465.197-202

Oloan, N. (2016). Praktek Pembuatan Akta Tanah oleh Camat dalam Kedudukan dan Fungsinya Selaku PPAT Sementara di Kota Padangsidimpuan. IUPIIS: IURNAL PENDIDIKAN ILMU-ILMU SOSIAL, 8(2), doi https://doi.org/10.24114/jupiis.v8i2.5158.g4578

Pradhipta, Y. R., \& Imanullah, M. N. (2019). Tanggung Jawab Notaris Dalam Kelalaian Membuat Akta Jual Beli Tanpa Melihat Dokumen Asli (Studi Kasus Putusan Peninjauan Kembali Perkara Perdata No. 49. Pk/Pdt/2009 Tanggal 16 September 2009). Jurnal Repertorium, 6(1), 16. ISSN 2355-2646 , https://jurnal.uns.ac.id/repertorium/article/view/27830/19194

Ridodi, M. A. (2017). Batasan Kewenangan Notaris dan PPAT dalam Membuat Akta yang Berkaitan dengan Tanah. Lambung Mangkurat Law Journal, 2(1), 144735, eISSN: 2502-3128, http://lamlaj.ulm.ac.id/web/,

Tjukup, I. K., Layang, I. W. B. S., Martana, N. A., Markeling, I. K., Dananjaya, N. S., Arsha, I. P. R., ... \& Tribuana, P. A. R. (2016). Akta Notaris (Akta Otentik) Sebagai Alat Bukti Dalam Peristiwa Hukum Perdata. Jurnal Ilmiah Prodi Magister Kenotariatan, 2015, 180, doi https://doi.org/10.24843/AC.2016.v01.i02.p05.

Wibawa, K. C. S. (2019). Menakar Kewenangan dan Tanggung Jawab Pejabat Pembuat Akta Tanah (PPAT) dalam Perspektif Bestuurs Bevoegdheid. CREPIDO, 1(1), 40-51, doi https://doi.org/10.14710/crepido.1.1.40-51

\section{$\underline{\text { Tesis }}$}

Widodo, MuhkamArief. (2015). Pertangqungiawaban Perdata Notaris Akibat Penyalahounaan Kerahasiaan Minuta Akta Oleh Pekerjanya. (Magister thesis, Universitas Brawijaya).

\section{Peraturan Perundang-Undangan}

Undang-Undang Dasar Negara Republik Indonesia Tahun 1945

Kitab Undang-Undang Hukum Perdata 
Undang-Undang Nomor 5 Tahun 1960 tentang Peraturan Dasar Pokok-Pokok Agraria (Lembaran Negara 1960-104, Tambahan Lembaran Negara Nomor 2043)

Undang-Undang Nomor 2 Tahun 2014 Tentang Perubahan Atas Undang-Undang Nomor 30 Tahun 2004 Tentang Jabatan Notaris (Lembaran Negara Republik Indonesia Tahun 2014 Nomor 3, Tambahan Lembaran Negara Republik Indonesia Nomor 5491)

Undang-Undang Nomor 8 Tahun 1974 tentang Pokok-Pokok Kepegawaian (Lembaran Negara Republik Indonesia Tahun 1974 Nomor 55, Tambahan Lembaran Negara Republik Indonesia Nomor 3041).

Peraturan Pemerintah Nomor 37 Tahun 1998 tentang Peraturan Jabatan Pejabat Pembuat Akta Tanah 